\title{
Contribution of forest floor fractions to carbon storage and abundance patterns of arbuscular mycorrhizal fungal colonisation in a tropical montane forest
}

\begin{abstract}
Forest floor carbon stocks, which include different components of litter, hemic and sapric materials, have not been empirically quantified in tropical montane forest, although they influence soil carbon (C) pools. To date, the contribution of arbuscular mycorrhizae in $\mathrm{C}$ sequestration potentials in tropical montane forests have not been clearly investigated. This study determined the amount of $\mathrm{C}$ stocks in the different decomposing layers of forest floor, mainly litter, hemic and sapric materials. The abundance of arbuscular mycorrhizal root colonisation differed among forest floor fractions. Forest floor was measured for depth, area density, dry mass and carbon fraction separately in Sungai Kial Forest Reserve, Pahang, Malaysia to calculate $\mathrm{C}$ stocks. Percentages of root colonisation in the hemic and sapric materials were investigated. The results showed that forest floor $\mathrm{C}$ stocks were significantly higher in hemic $\left(5 \mathrm{Mg} \mathrm{C} \mathrm{ha}^{-1}\right)$ and sapric $\left(7.7 \mathrm{Mg} \mathrm{C} \mathrm{ha}^{-1}\right)$ compared with the litter fragments $\left(1.5 \mathrm{Mg} \mathrm{C} \mathrm{ha}^{-1}\right)$. Mycorrhizal root colonisation was significantly higher (75\%) in the toeslope compared with the summit area in the hemic materials. Segregation of forest floor layers provided greater accuracy in forest floor $\mathrm{C}$ stocks reporting.
\end{abstract}

Keyword: Carbon stocks; High altitudes; Mycorrhizal associations; Organic layer; Tropics 